\title{
Severe but reversible pulmonary hypertension in scleromyxedema and multiple myeloma: a case report
}

\author{
Mazen Kreidy ${ }^{1,5^{*}}$, Ali Al-Hilli ${ }^{2}$, Ralph Yachoui ${ }^{3}$ and Jeffrey Resnick ${ }^{4}$
}

\begin{abstract}
Background: Scleromyxedema is a progressive, systemic connective tissue disorder characterized by fibro-mucous skin lesions and increased serum monoclonal immunoglobulin levels. Pulmonary involvement occurs in a subset of patients, though the overall prevalence of pulmonary lesions in scleromyxedema is unknown. Since pulmonary hypertension presumably occurs in these patients due to disease progression and development of additional conditions, treatment of the underlying plasma cell dyscrasia and connective tissue disorder may improve pulmonary hypertension symptoms.

Case presentation: An elderly patient with scleromyxedema developed pulmonary hypertension refractory to vasodilator and diuretic therapy and subsequently multiple myeloma that responded to a combination therapy of bortezomib, cyclophosphamide, and dexamethasone treatment.

Conclusions: Treatment of the underlying disease(s) that contributed to pulmonary hypertension development with anti-neoplastic agents like bortezomib may improve cardiopulmonary symptoms secondary to reducing abnormal blood cell counts and paraprotein levels.
\end{abstract}

Keywords: Scleromyxedema, Pulmonary hypertension, Multiple myeloma, Bortezomib, Cyclophosphamide, Dexamethasone

\section{Background}

Scleromyxedema (papular mucinosis, generalized lichen myxedematous, Arndt-Gordon disease) is a rare, chronic, progressive disorder characterized by skin lesions with mucinous material deposition, fibrosis, increased population of fibroblasts, and high levels of immunoglobulins (monoclonal gammopathy of unknown significance [MGUS]) in serum without a corresponding thyroid abnormality [1-11]. In a subset of cases described by Rongioletti et al., immune cell infiltrates may also be present in skin lesions in a "granuloma annulare-like pattern" [7]. Scleromyxedema is a multi-organ disorder that can involve the nervous system, lungs, heart, kidneys, esophagus, larynx, eyes, muscles, bone marrow, and skin [2-11]. Death can occur due to organ involvement

\footnotetext{
* Correspondence: mazenkreidy@hotmail.com

'Department of Pulmonary and Critical Care Medicine, Marshfield Clinic, Marshfield, WI, USA

${ }^{5}$ Present affiliation: Christiana Care Health System, PO Box 1668, Wilmington, DE 19899, USA

Full list of author information is available at the end of the article
}

or evolution into a blood malignancy or other cancer $[2-4,6,8,10-19]$. In a 2013 retrospective study of 30 scleromyxedema cases, two patients died from Hodgkin lymphoma or myeloid leukemia at 22 months and 11 years post-scleromyxedema diagnosis, respectively, without undergoing melphalan treatment (a chemotherapeutic agent associated with development of hematological malignancies) $[2,3,6,8,12]$. Treatment generally involves modulating the immune system, decreasing the population of plasma cells, and/or improving dermatological manifestations of the disease; pharmacological and surgical treatments include intravenous immunoglobulin (IVIG), thalidomide/thalidomide derivative lealidomide, systemic glucocorticoids, melphalan, bortezomib plus dexamethasone, and autologous stem cell transplantation among others $[2-6,8-14,16-41]$.

As a dermatological condition with disease characteristics similar to scleroderma, scleromyxedema is generally classified as a connective tissue disorder with associated immune system/inflammatory responses, but due to the abnormal 
amounts of monoclonal immunoglobulin produced (paraproteinemia) and associated abnormal plasma cell populations, scleromyxedema is also considered a paraneoplastic and hematologic disorder [1-11, 36]. In these contexts, many scleromyxedema-associated syndromes can develop, including pulmonary hypertension (PH), myeloproliferative neoplasms (MPN), leukemia/lymphoma, and multiple myeloma [1, 6, 8-22, 24-27, 29, 31-33, 35-37, 39-41]. PH, defined by a mean pulmonary arterial pressure of $\geq 25 \mathrm{mmHg}$ at rest, can also occur in patients with MPN and other paraneoplastic conditions, and it is demonstrated in the medical literature that PH symptoms improve in response to treatment when the underlying MPN is targeted [25, 42-63]. Therefore, prescribing treatment regimens that target the overlapping pathophysiological characteristics of these associated conditions may simultaneously improve symptomology in patients with multi-system scleromyxedema [2, 13, 17, 19-22, 24-26, 36].

In this case report, we describe the diagnosis, treatment, and progression of $\mathrm{PH}$ in a patient who had scleromyxedema and developed multiple myeloma refractory to triple $\mathrm{PH}$ treatment that resolved with a combination treatment of bortezomib, cyclophosphamide, and dexamethasone. We propose that combination therapy with the anti-neoplastic agent bortezomib is an important adjuvant therapy to reverse vasodilator resistant $\mathrm{PH}$ in patients with scleromyxedema and plasma cell dyscrasias.

\section{Case presentation}

A 77-year-old male nonsmoker with a history of atrial fibrillation and sick sinus syndrome post-pacemaker placement experienced edema, skin rash, and skin tightening. During the initial physical examination, yellow-brown papules and indurated and pendulous skin folds were evident on his face, neck, retroauricular area, chest, trunk, upper extremities, and thighs; he also had difficulty opening his mouth. No gross changes were observed in the digital nail beds (i.e., pitting and capillary loops) but were present in the lower extremities. Edema was present in the lower extremities. Skin biopsies revealed fibrosis and benign fibrocytic proliferation consistent with scleromyxedema (Fig. 1a). Colloidal iron staining for mucin deposition detected minimal interstitial mucin deposition in one biopsy, although Verhoeff van Gieson elastic stain highlighted fragmentation of superficial dermal collagen bundles (Fig. 1b and c). Congo red stain for amyloid deposition was negative. Aside from telangiectasia, there was no evidence of vasculopathy or thrombosis associated with these lesions. Laboratory testing of serum and urine samples detected an elevated level of immunoglobulin G (IgG) production, consistent with a diagnosis of MGUS. Electrophoresis of serum proteins revealed a total IgG level of $1500 \mathrm{mg} / \mathrm{dL}$. Elevated levels of two IgG lambda monoclonal antibodies $(\sim 0.4 \mathrm{~g} / \mathrm{dL}$ each) with a kappa to lambda ratio of 0.28 were detected by immunofixation of serum samples. The remaining blood values were normal for hemoglobin and calcium levels, but the patient's kidney function was slightly above normal (creatinine level was $1.4 \mathrm{mg} / \mathrm{dL}$ and estimated glomerular filtration rate [eGFR] was $54 \mathrm{~mL} / \mathrm{min} / 1.73 \mathrm{~m}^{2}$ ). A 24-h urine sample was positive for lambda Bence-Jones protein at levels too low to quantitate by immunofixation. Although a skeletal survey was negative for lytic lesions, bone marrow biopsies contained $4.7 \%$ of mature looking plasma cells.

Additional diagnostic work-up did not suggest multiorgan involvement with scleromyxedema; initial spirometry testing and diffusion lung capacity for carbon monoxide (DLCO) were within normal limits. An echocardiogram indicated the patient had diastolic dysfunction but otherwise normal right and left cardiac function and size with a normal pulmonary artery systolic pressure of $27 \mathrm{mmHg}$. He was placed on intravenous immunoglobulin $\mathrm{G}$ therapy at a dosage of $40 \mathrm{~g} / \mathrm{mL}$ administered every 6 weeks, with a daily regimen of $60 \mathrm{mg}$ prednisone and $200 \mathrm{mg}$ hydroxychloroquine twice daily. There was significant improvement in the patient's skin symptoms, and 8 weeks later, his prednisone regimen was weaned down to $5 \mathrm{mg}$ per day. The patient was also started on a thalidomide regimen with an initial dose of $100 \mathrm{mg}$ per day. His IgG levels decreased to

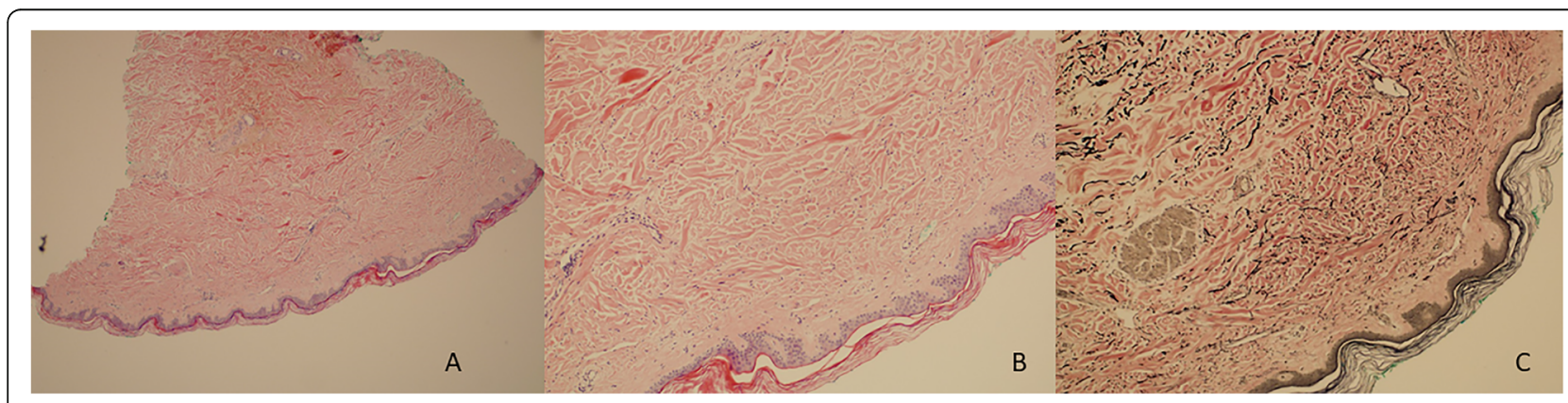

Fig. 1 Pathology analysis of skin biopsies highlighting fibrosis and fibrocytic proliferation indicative of scleromyxedema using a Hematoxylin and Eosin stain, b colloidal iron staining for mucin deposition, and c Verhoeff van Gieson elastic stain 
$600 \mathrm{mg} / \mathrm{dL}$ after one year of maintenance therapy with this regimen.

Over the following 4 years post-scleromyxedema diagnosis, the patient had three recurrences of dermatological symptoms of increasing severity. Episodes of acute symptoms were managed by a burst dose and tapering of steroid medication (prednisone at $60 \mathrm{mg}$ daily until resolution of symptoms then a rapid taper to a maintenance dose of 5 $\mathrm{mg}$ daily) and increased dose of IVIG. Thalidomide treatment was discontinued 2 years later due to neuropathy, and hydroxychloroquine treatment was considered inefficient for ameliorating symptoms. During this period of time, the patient's total IgG levels slowly increased to $1700 \mathrm{mg} / \mathrm{dL}$ with concurrent elevations in lambda monoclonal proteins ranging from $0.4-0.5 \mathrm{mg} / \mathrm{dL}$ and $0.6-0.7 \mathrm{mg} / \mathrm{dL}$.

At 4 years post-diagnosis, he experienced an acute episode of skin symptoms and severe dyspnea. Severely elevated levels of brain natriuretic peptide (BNP) $(2650 \mathrm{pg} /$ $\mathrm{mL}$ ), indicative of cardiac strain, were detected in serum, and echocardiographic analysis revealed an enlarged right heart with depressed systolic function and an elevated pulmonary arterial systolic pressure estimated at $70 \mathrm{mmHg}$. Left ventricular function and size was normal. Abnormal pulmonary hemodynamics (in $\mathrm{mm} \mathrm{Hg}$ ) were measured by right heart catheterization, specifically, pulmonary artery pressures of 66/30/42, wedge pressure of 12 , right ventricular pressures at 66/15, and right atrial pressure at 13 . The pulmonary vascular resistance was estimated at 8.2 international units (IU), while the cardiac output was elevated at $3.65 \mathrm{~L} / \mathrm{min}$. Pulmonary function testing revealed a low DLCO at $50 \%$. A chest computed tomography (CT) scan excluded embolism and parenchymal lung disease as contributing factors to elevated right heart dimensions and pulmonary hemodynamics. Additional laboratory testing of serum proteins detected elevated levels of IgG proteins $(3670 \mathrm{mg} / \mathrm{dL})$ and the two lambda monoclonal proteins $(1.6 \mathrm{~g} / \mathrm{dL}$ and $1.3 \mathrm{~g} / \mathrm{dL})$. A follow-up bone marrow biopsy revealed an $\sim 10 \%$ normal appearing population of plasma cells that were considered reactive to the patient's underlying scleromyxedema.

Based on the cardiovascular, pulmonary, and hematological analyses, the patient was diagnosed with a scleromyxedema flare with associated pulmonary arterial hypertension (PAH). He was initially placed on a dual treatment regimen for PAH consisting of $40 \mathrm{mg}$ tadalafil once daily and ambrisentan $5 \mathrm{mg}$ daily that was later increased to $10 \mathrm{mg}$ daily. In addition to increasing the ambrisentan dosage, a daily dose of $40 \mathrm{mg}$ lasix was added to the PAH treatment. Scleromyxedema treatment was optimized with the addition of intravenous chimeric antibodies against CD20 (rituximab) at a dosage and frequency similar to a protocol for rheumatoid arthritis, specifically $1 \mathrm{~g}$ of rituximab on days 1 and 15 of the treatment cycle over a period of 24weeks for a total regimen of three cycles. A burst-taper dose of prednisone was also administered $(60 \mathrm{mg}$, tapered over the next 8 weeks). Over the following year, inhaled trepostinil (vasodilator) was added to the PAH regimen for persistently elevated pulmonary arterial systolic pressure at $42 \mathrm{mmHg}$ and right heart strain on cardiac echography.

On this treatment regimen, the patient's acute symptoms improved, and he maintained a New York Heart Association (NYHA) functional status of class II. Although the patient's serum BNP levels decreased to $300 \mathrm{pg} / \mathrm{mL}$, echocardiographic analysis continued to show depressed right heart function and elevated pulmonary arterial pressure at $43 \mathrm{mmHg}$. A polysomnographic analysis indicated the patient had developed obstructive sleep apnea (Apnea-Hypopnea Index [AHI] of 24 events/hour), and he was subsequently treated with continuous positive airway pressure (CPAP) at $10 \mathrm{cmH} 2 \mathrm{O}$. Intravenous prostacyclin therapy was considered for $\mathrm{PAH}$, but the patient declined. Follow-up immunoglobulin analysis revealed decreased IgG levels $(2060 \mathrm{mg} / \mathrm{dL})$.

Despite maintenance therapy with IVIG and rituximab, the patient developed another severe recurrence of his skin symptoms and worsening dyspnea at 6 years postscleromyxedema diagnosis (2 years post-PAH diagnosis). Follow-up echocardiography revealed a new left ventricular cardiomyopathy with an ejection fraction of $40 \%$, persistent elevated pulmonary arterial pressure at $44 \mathrm{mmHg}$, and persistent right ventricular dilation. Serum BNP levels were elevated at $631 \mathrm{pg} / \mathrm{mL}$, and IgG levels had increased to 3420 $\mathrm{mg} / \mathrm{dL}$ with concurrent elevations of the two monoclonal lambda proteins at 1.48 and $0.37 \mathrm{~g} / \mathrm{dL}$. A follow-up bone marrow biopsy revealed an abnormal plasma cell population of $60 \%$ consistent with a hematological abnormality. The patient was diagnosed with multiple myeloma associated with an acute episode of scleromyxedema flare up with multi-organ involvement. A treatment regimen of bortezomib (2 mg; dose adjusted per cycle depending on patientrelated factors as denoted in Table 1) and dexamethasone (20 mg) (4 weeks per cycle of therapy) was initiated to decrease the plasma cell population, and IVIG treatment was continued to alleviate dermatological symptoms. Over the following 2 years, the patient received a total of seven cycles of bortezomib and dexamethasone (Table 1). There was a dramatic improvement in his PAH, cardiovascular, and dermatological symptoms. Serum analysis revealed decreased BNP and IgG levels at $100 \mathrm{pg} / \mathrm{mL}$ and $1300 \mathrm{mg}$, respectively. A repeat echocardiogram revealed significant improvement in right ventricular size and function as well as left ventricular function, but pulmonary arterial systolic pressure was still elevated at $51 \mathrm{mmHg}$. However, bortezomib had to be discontinued after the seventh cycle due to worsening neuropathy. A treatment regimen with a lenalidomide derivative (Revlimid) was attempted but also discontinued after 2 months of treatment due to adverse side effects. The patient elected to halt the inhaled trepostinil regimen. 
Table 1 Chemotherapeutic regimens administered with bortezomib for treatment of multiple myeloma and pre-existing scleromyxedema with pulmonary symptoms

\begin{tabular}{|c|c|c|c|c|c|c|c|c|}
\hline $\begin{array}{l}\text { Cycle } \\
\#\end{array}$ & Agent 1 & Dose & Agent 2 & Dose & Agent 3 & Dose & Agent 4 & Dose \\
\hline 1 & Bortezomib D1, D8, D15 & $2.5 \mathrm{IV}$ & $\begin{array}{l}\text { Dexamethasone } \\
\text { Weekly }\end{array}$ & $\begin{array}{l}20 \mathrm{mg} \\
\mathrm{PO}\end{array}$ & IVIG Weekly & $40 \mathrm{~g} \mathrm{IV}$ & - & - \\
\hline 2 & Bortezomib D1, D8, D15 & $2.6 \mathrm{~S} / \mathrm{Q}$ & $\begin{array}{l}\text { Dexamethasone } \\
\text { Weekly }\end{array}$ & $\begin{array}{l}20 \mathrm{mg} \\
\mathrm{PO}\end{array}$ & IVIG Weekly & $40 \mathrm{~g} \mathrm{IV}$ & - & - \\
\hline 3 & Bortezomib D1, D8, D15 & $2.6 \mathrm{~S} / \mathrm{Q}$ & $\begin{array}{l}\text { Dexamethasone } \\
\text { Weekly }\end{array}$ & $\begin{array}{l}20 \mathrm{mg} \\
\mathrm{PO}\end{array}$ & IVIG Weekly & $40 \mathrm{~g} \mathrm{IV}$ & - & - \\
\hline 4 & Bortezomib D1, D8, D15 & $2.6 \mathrm{~S} / \mathrm{Q}$ & $\begin{array}{l}\text { Dexamethasone } \\
\text { Weekly }\end{array}$ & $\begin{array}{l}20 \mathrm{mg} \\
\mathrm{PO}\end{array}$ & IVIG Weekly & $40 \mathrm{~g} \mathrm{IV}$ & - & - \\
\hline 5 & Bortezomib D1, D8, D15 & $2.6 \mathrm{~S} / \mathrm{Q}$ & $\begin{array}{l}\text { Dexamethasone } \\
\text { Weekly }\end{array}$ & $\begin{array}{l}20 \mathrm{mg} \\
\mathrm{PO}\end{array}$ & IVIG Weekly & $40 \mathrm{~g} \mathrm{IV}$ & - & - \\
\hline 6 & Bortezomib D1, D8, D15 & $2.6 \mathrm{~S} / \mathrm{Q}$ & $\begin{array}{l}\text { Dexamethasone } \\
\text { Weekly }\end{array}$ & $\begin{array}{l}20 \mathrm{mg} \\
\mathrm{PO}\end{array}$ & IVIG Weekly & $40 \mathrm{~g} \mathrm{IV}$ & - & - \\
\hline 7 & $\begin{array}{l}\text { Bortezomib D1 only, developed } \\
\text { neuropathy }\end{array}$ & $2.6 \mathrm{~S} / \mathrm{Q}$ & $\begin{array}{l}\text { Dexamethasone } \\
\text { Weekly }\end{array}$ & $\begin{array}{l}20 \mathrm{mg} \\
\mathrm{PO}\end{array}$ & IVIG Weekly & $40 \mathrm{~g} \mathrm{IV}$ & & \\
\hline 1 & Bortezomib D1, D8, D15 & $\begin{array}{l}1.5 \mathrm{mg} \\
\text { IV }\end{array}$ & $\begin{array}{l}\text { Dexamethasone } \\
\text { Weekly }\end{array}$ & $\begin{array}{l}20 \mathrm{mg} \\
\mathrm{PO}\end{array}$ & $\begin{array}{l}\text { Cyclophosphamide D1, D8, } \\
\text { D15 }\end{array}$ & $\begin{array}{l}300 \mathrm{mg} \\
\text { IV }\end{array}$ & $\begin{array}{l}\text { IVIG } \\
\text { Weekly }\end{array}$ & $\begin{array}{l}40 \mathrm{~g} \\
\mathrm{IV}\end{array}$ \\
\hline 2 & Bortezomib D1, D8, D15 & $\begin{array}{l}1.5 \mathrm{mg} \\
\text { IV }\end{array}$ & $\begin{array}{l}\text { Dexamethasone } \\
\text { Weekly }\end{array}$ & $\begin{array}{l}20 \mathrm{mg} \\
\mathrm{PO}\end{array}$ & $\begin{array}{l}\text { Cyclophosphamide D1, D8, } \\
\text { D15 }\end{array}$ & $\begin{array}{l}300 \mathrm{mg} \\
\text { IV }\end{array}$ & $\begin{array}{l}\text { IVIG } \\
\text { Weekly }\end{array}$ & $\begin{array}{l}40 \mathrm{~g} \\
\mathrm{IV}\end{array}$ \\
\hline 3 & Bortezomib D1, D8, D15 & $\begin{array}{l}1.6 \mathrm{mg} \\
\mathrm{IV}\end{array}$ & $\begin{array}{l}\text { Dexamethasone } \\
\text { Weekly }\end{array}$ & $\begin{array}{l}20 \mathrm{mg} \\
\mathrm{PO}\end{array}$ & $\begin{array}{l}\text { Cyclophosphamide D1, D8, } \\
\text { D15 }\end{array}$ & $\begin{array}{l}600 \mathrm{mg} \\
\text { IV }\end{array}$ & $\begin{array}{l}\text { IVIG } \\
\text { Weekly }\end{array}$ & $\begin{array}{l}40 \mathrm{~g} \\
\mathrm{IV}\end{array}$ \\
\hline 4 & Bortezomib D1, D8, D15 & $\begin{array}{l}1.6 \mathrm{mg} \\
\text { IV }\end{array}$ & $\begin{array}{l}\text { Dexamethasone } \\
\text { Weekly }\end{array}$ & $\begin{array}{l}20 \mathrm{mg} \\
\mathrm{PO}\end{array}$ & $\begin{array}{l}\text { Cyclophosphamide D1, D8, } \\
\text { D15 }\end{array}$ & $\begin{array}{l}600 \mathrm{mg} \\
\text { IV }\end{array}$ & $\begin{array}{l}\text { IVIG } \\
\text { Weekly }\end{array}$ & $\begin{array}{l}40 \mathrm{~g} \\
\mathrm{IV}\end{array}$ \\
\hline \multicolumn{2}{|c|}{ Chemotherapy break- } & - & $\begin{array}{l}\text { Dexamethasone } \\
\text { Weekly }\end{array}$ & $\begin{array}{l}20 \mathrm{mg} \\
\mathrm{PO}\end{array}$ & - & - & $\begin{array}{l}\text { IVIG } \\
\text { Weekly }\end{array}$ & $\begin{array}{l}40 \mathrm{~g} \\
\mathrm{IV}\end{array}$ \\
\hline 5 & Bortezomib D1, D8, D15 & $\begin{array}{l}1.2 \mathrm{mg} \\
\mathrm{IV}\end{array}$ & $\begin{array}{l}\text { Dexamethasone } \\
\text { Weekly }\end{array}$ & $\begin{array}{l}20 \mathrm{mg} \\
\mathrm{PO}\end{array}$ & $\begin{array}{l}\text { Cyclophosphamide D1, D8, } \\
\text { D15 }\end{array}$ & $\begin{array}{l}600 \mathrm{mg} \\
\text { IV }\end{array}$ & $\begin{array}{l}\text { IVIG } \\
\text { Weekly }\end{array}$ & $\begin{array}{l}40 \mathrm{~g} \\
\mathrm{IV}\end{array}$ \\
\hline 6 & Bortezomib D1, D8, D15 & $\begin{array}{l}1.5 \mathrm{mg} \\
\text { IV }\end{array}$ & $\begin{array}{l}\text { Dexamethasone } \\
\text { Weekly }\end{array}$ & $\begin{array}{l}20 \mathrm{mg} \\
\mathrm{PO}\end{array}$ & $\begin{array}{l}\text { Cyclophosphamide D1, D8, } \\
\text { D15 }\end{array}$ & $\begin{array}{l}480 \mathrm{mg} \\
\text { IV }\end{array}$ & $\begin{array}{l}\text { IVIG } \\
\text { Weekly }\end{array}$ & $\begin{array}{l}40 \mathrm{~g} \\
\mathrm{IV}\end{array}$ \\
\hline 7 & Bortezomib D1, D8, D15 & $2 \mathrm{mg}$ IV & $\begin{array}{l}\text { Dexamethasone } \\
\text { Weekly }\end{array}$ & $\begin{array}{l}20 \mathrm{mg} \\
\mathrm{PO}\end{array}$ & $\begin{array}{l}\text { Cyclophosphamide D1, D8, } \\
\text { D15 }\end{array}$ & $\begin{array}{l}600 \mathrm{mg} \\
\text { IV }\end{array}$ & $\begin{array}{l}\text { IVIG } \\
\text { Weekly }\end{array}$ & $\begin{array}{l}40 \mathrm{~g} \\
\mathrm{IV}\end{array}$ \\
\hline 8 & Bortezomib D1, D8, D15 & $\begin{array}{l}1.6 \mathrm{mg} \\
\mathrm{IV}\end{array}$ & $\begin{array}{l}\text { Dexamethasone } \\
\text { Weekly }\end{array}$ & $\begin{array}{l}20 \mathrm{mg} \\
\mathrm{PO}\end{array}$ & $\begin{array}{l}\text { Cyclophosphamide D1, D8, } \\
\text { D15 }\end{array}$ & $\begin{array}{l}600 \mathrm{mg} \\
\text { IV }\end{array}$ & $\begin{array}{l}\text { IVIG } \\
\text { Weekly }\end{array}$ & $\begin{array}{l}40 \mathrm{~g} \\
\mathrm{IV}\end{array}$ \\
\hline \multirow[t]{3}{*}{9} & Bortezomib D1, D8, D15 & $2 \mathrm{mg} \mathrm{IV}$ & $\begin{array}{l}\text { Dexamethasone } \\
\text { Weekly }\end{array}$ & $\begin{array}{l}20 \mathrm{mg} \\
\mathrm{PO}\end{array}$ & $\begin{array}{l}\text { Cyclophosphamide D1, D8, } \\
\text { D15 }\end{array}$ & $\begin{array}{l}500 \mathrm{mg} \\
\text { IV }\end{array}$ & $\begin{array}{l}\text { IVIG } \\
\text { Weekly }\end{array}$ & $\begin{array}{l}40 \mathrm{~g} \\
\mathrm{IV}\end{array}$ \\
\hline & Iron infusion & $\begin{array}{l}510 \mathrm{mg} \\
\mathrm{IV}\end{array}$ & - & - & - & - & - & - \\
\hline & Passed away & N/A & N/A & N/A & N/A & N/A & N/A & N/A \\
\hline
\end{tabular}

Abbreviations: D\# Day of treatment cycle, IV Intravenous Injection, IVIG Intravenous Immunoglobulin, N/A Not applicable, PO Per Os (oral), S/Q Subcutaneos Injection, - unknown

The patient was observed for $\sim 14$ months before he experienced a recurrence of symptoms and cardiopulmonary decline. His IgG levels had again increased to $2000 \mathrm{mg} / \mathrm{dL}$. The patient was placed on a weekly regimen of $3 \mathrm{mg}$ bortezomib, $20 \mathrm{mg}$ dexamethasone, and $600 \mathrm{mg}$ of cyclophosphamide (Cytoxan) (4weeks per cycle, last dose omitted because of pancytopenia), and IVIG maintenance therapy was continued at a dosage of $40 \mathrm{~g} / \mathrm{mL}$ (see Table 1 for dose adjustments per cycle). After four cycles, the patient's symptoms improved, and his IgG levels decreased to the lowest concentration of $1100 \mathrm{mg} / \mathrm{dL}$. Only one monoclonal lambda protein was detected at $0.52 \mathrm{mg} / \mathrm{dL}$. An echocardiogram revealed normalization of left and right ventricular size and function as well as normalization of pulmonary arterial systolic pressure at $23 \mathrm{mmHg}$.

After a treatment break of 6 months, the patient's symptoms recurred, and his IgG levels increased above $2000 \mathrm{mg} /$ $\mathrm{dL}$. The patient underwent five additional cycles of bortezomib, dexamethasone, and cyclophosphamide. His IgG levels stabilized between 2000 and $2500 \mathrm{mg} / \mathrm{dL}$, and a repeat bone marrow biopsy revealed a decrease in the abnormal plasma cell population to $22 \%$. A follow-up echocardiogram revealed normal right and left ventricular size and function 
and a mildly elevated pulmonary arterial systolic pressure at $38 \mathrm{mmHg}$. Future plans for the patient's care involved slowly weaning him from his vasodilator medications; however, he suffered a sudden and fatal out-of-hospital cardiac arrest of unclear etiology at 9 years post-scleromyxedema diagnosis. No autopsy was performed.

\section{Discussion}

Pulmonary hypertension has occurred in association with various hematologic malignancies, particularly those with underlying plasma cell dyscrasias [25, 42-63]. The first case of reversible $\mathrm{PH}$ in response to antineoplastic treatment for a scleromyxedema-like condition and hematological malignancy was described by Yaqub et al. in 2004, and in 2015, Feyereisn described the diagnosis, treatment, and outcome of four cases of reversible $\mathrm{PH}$ in the setting of plasma cell dyscrasias one of which had scleromyxedema [24, 25]. The overall frequency and spectrum of $\mathrm{PH}$ in this setting remains largely undefined.

In our patient with scleromyxedema, multiple antineoplastic and immunomodulatory treatment regimens were used to alleviate dermatological and cardiopulmonary symptoms. Immunomodulatory treatments like IVIG, glucocorticoids, and hydroxychloroquine were administered over the entire course of the disease but were unable to produce a complete remission of skin and cardiopulmonary symptoms. Administration of anti-neoplastic agents like thalidomide and bortezomib led to decreased paraprotein levels on multiple occasions and corresponded to improved pulmonary dynamics in a manner similar to previously published cases $[24,25,27,60]$. Close monitoring and treatment alteration was necessary to prevent unanticipated clinical events. Thalidomide or thalidomide derivatives were used at two points over the course of this patient's history but were halted due to development of neuropathy and other adverse side effects. Although anti-neoplastic/chemotherapeutic agents can be associated with the development of $\mathrm{PH}$, pulmonary injury, and hematological malignancies, we do not believe this occurred based on the temporal progression of scleromyxedema from a localized cutaneous condition to a generalized disease with multiple phenotypes over a period of 9 years [2-4, 6, 8, 10-12, 47, 53, 64-80]. Furthermore, $\mathrm{PH}$ developed 2 years after thalidomide treatment was stopped, and cardiopulmonary symptoms for the most part resolved in response to multiple myeloma treatment. Despite a partial therapeutic response with respect to abnormal plasma cell populations and IgG production, this patient experienced excellent recovery of cardiopulmonary function when on anti-neoplastic treatment regimens. Thus, a complete remission of scleromyxedema and associated plasma cell dyscrasia and paraprotein levels does not appear to be necessary to obtain a significant improvement in PH symptoms.
Although the physiopathology of $\mathrm{PH}$ development in response to plasma cell dyscrasias has not been fully elucidated, the reversibility of hemodynamics in response to treatment with chemotherapeutic and immunomodulatory agents offers hope for PAH patients [24, 25, 27, 42, $43,45,50,53,57-60,62,63,81-103]$. Improvements in hematopoietic cell populations, paraprotein levels, and hemodynamic functions in our patient and other cases of reversible PH suggest that abnormal plasma cell populations play a central role in the development of $\mathrm{PH}$ $[24,25,27,43,45,50,53,57-60,62,63,81,84-86,91]$. Furthermore, patients with scleromyxedema and related conditions who received treatments traditionally used for multiple myeloma have exhibited decreases in IgG and paraprotein levels that co-occurred with clinical improvements, as in our patient $[17,20-25,31,35,60,61]$. This may also indicate a direct link between decreased paraprotein levels and hemodynamic improvements by way of improved hyperviscosity and associated microvascular dysfunction [8]. However, detectable paraprotein levels are not always present nor correspond to the severity, progression, and response of scleromyxedema to standard treatments for this condition; therefore, the relative contribution of scleromyxedema progression and paraprotein levels to $\mathrm{PH}$ development is unclear $[3,5,6$, $8,9,13,14,16-18,20-25,31,35,60,61]$. Other pathobiological mechanisms invoked in the development of scleromyxedema and/or associated with plasma cell dyscrasias may also contribute to the development of PAH. These include increased secretion and expression of cytokines, dysregulation of immune system activities, and/ or abnormal pulmonary fibroblasts, mucin deposition in the pulmonary vasculature, and direct invasion of the pulmonary vasculature by abnormal plasma cells $[2-4,8$, 11, 14-16, 18, 27, 29, 31-38, 41, 57, 62, 63, 81, 86, 87, 96, 104-111]. Alternatively, a direct effect of chemotherapeutic agents on the pulmonary vasculature and associated abnormal humoral milieus may also have played a role in this reversibility. Due to the multifaceted nature of $\mathrm{PH}$ development and reversibility in response to treatment, it is also possible that a multi-hit model, as in idiopathic pulmonary arterial hypertension (IPAH), is plausible [106]. Regardless of the underlying etiology, patients with concurrent $\mathrm{PH}$ and MPN or vice versa have demonstrated hemodynamic improvements in response to chemotherapeutic agents; thus, patients with vasodilator-resistant $\mathrm{PH}$ may derive benefit from cancer treatments [25, 27, 42-63].

Evidence for a cancer-like pathology and direct effects of immunosuppressive and anti-proliferative agents on $\mathrm{PH}$ development and progression is present in case reports for patients with PAH [24, 25, 42, 43, 45-55, 57, $58,60-63,76,81,85-87,90-96,105-107,110-113]$. According to Price et al., "Pathologic specimens from patients with $\mathrm{PAH}$ demonstrate an accumulation of 
perivascular inflammatory cells," and laboratory analysis of serum from patients with PAH revealed increased levels of cytokines, chemokines as well as autoantibodies to endothelial cells and fibroblasts [105, 108, 109]. In parallel to those abnormalities, the pulmonary vascular cells of patients with PAH exhibit many features of cancerous cells from dysregulated metabolism to increased cell proliferation and resistance to apoptosis [106, 109]. These observations combined with the occurrence of $\mathrm{PAH}$ in various connective tissue diseases support the role of inflammation, autoimmunity, and a neoplastic-like dysregulation at the center of the pathogenesis of PAH [105-107, 110-113]. This model could provide a mechanistic explanation for the hemodynamic improvements noted in our patient and in many patients with PAH in response to immunosuppressive and anti-proliferative agents [24, 25, 27, 42-63]. The following paragraphs provide a description of currently used agents for multiple myeloma and/or scleromyxedema that have proven effective for patients with PAH.

Glucocorticoids have an inhibitory effect on multiple types of immune cells and produce broad anti-inflammatory and immunosuppressive effects [114]. Glucocorticoids have been used as a treatment for scleromyxedema with positive effects reported in single case reports, and its efficacy against collagen disease-associated PAH is well known [31-35, 84, 88-90, 112-114]. Glucocorticoids are also used as a first line therapy for multiple myeloma in combination with other chemotherapy regimens in patients ineligible for autologous stem cell transplantation [115]. Improvements post-prednisolone treatment have been noted in adult and pediatric patients with $\mathrm{iPAH}$ as well as in monocrotaline-induced pulmonary arterial hypertension in rodents [88-90, 96, 97].

Rituximab is an FDA-approved chimeric anti-CD20 monoclonal antibody for various malignancies and autoimmune disorders [116]. It exerts its immunosuppressive and antiproliferative effects through antibody- and complementmediated dependent cellular toxicity and apoptosis and has been used anecdotally for mixed connective tissue disorders [91, 112, 116]. Previously published case reports demonstrated improvements in collagen vascular disease-associated $\mathrm{PAH}$ in response to rituximab treatment, and a large randomized placebo controlled clinical trial of rituximab for the treatment of scleroderma-associated PAH is currently underway (ClinicalTrials.gov identifier NCT01086540) [92, 93]. In a presumed case of iPAH, rituximab co-treatment with chemotherapy for lymphoma lead to symptom resolution, and PAH in the setting of Castleman lymphoma was also noted to respond to rituximab $[63,85]$. However, in two instances, rituximab use was associated with the development of $\mathrm{PH}[79,80]$.

Plasma exchange or plasmapheresis is an automated technique that permits the selective therapeutic exchange of patient plasma with another fluid. Plasma exchange has been suggested as a treatment for scleromyxedema and was noted to improve $\mathrm{PAH}$ in association with various connective tissue diseases $[37,38,86]$. Immunoadsorption (IA), another extracorporeal automated technique to selectively remove immunoglobulins from the plasma of $\mathrm{PAH}$ patients via high affinity absorbers, is a promising treatment for iPAH; in 5 patients with severe iPAH awaiting transplant, IA improved symptoms associated with iPAH [94]. IA as an add-on to targeted medical therapy also led to improvements in mean PVR and CI in 10 patients with iPAH though these hemodynamic improvements did not correlate to substantial improvements in the $6 \mathrm{mn}$ walk test [95].

Bortezomib is a proteasome inhibitor that is FDAapproved for the treatment of multiple myeloma $[117,118]$. In the medical literature, patients with multiple myeloma and $\mathrm{PH}$ can experience reversal of $\mathrm{PH}$ symptoms with bortezomib treatment, although adverse pulmonary effects have also been reported in association with this drug [25, 64-71, 73, 75, 76]. Steroid co-treatments can prevent bortezomib-induced lung injury, though additional studies are needed to assess both the adverse pulmonary side effects as well as the protective effect of an adjuvant steroid regimen for bortezomib treatment [64-71, 73, 75, 76]. In animal models of pulmonary disease, bortezomib treatment reverses adverse cardiopulmonary effects and can improve survival post-monocrotaline-induced $\mathrm{PH} / \mathrm{PAH}$ [98-103]. In a mouse model of hypoxia-induced $\mathrm{PH}$, bortezomib treatment prevented an increase in right ventricular systolic pressure, ratio of right ventricular weight to left ventricular weight and septum (right ventricular hypertrophy index), percent medial wall thickness, and muscularization of pulmonary vessels and inhibited vascular smooth muscle proliferation [98]. A similar treatment effect was observed in rats with monocrotaline- or left-to-right shunt-induced $\mathrm{PAH}$, and bortezomib treatment also enhanced survival in monocrotaline-injected rats compared to monocrotalineinjected rats without bortezomib treatment [98-102]. In a chronic hypoxia-induced PAH rat model, Ibrahim and colleagues noted that anti-tumor agents, specifically bortezomib, MG-132, and daunorubicin, decreased pulmonary vessel thickness and, in the case of daunorubicin and MG132, improved pulmonary response to vasodilator treatment [103]. Together, these results suggest that proteasome inhibitors alone or in combination with vasodilators could potentially prevent and/or reverse PAH-induced pulmonary vessel remodeling and hemodynamic response in $\mathrm{PAH}$ afflicted patients [98-103].

Regardless of the agent selected, it is clear from our and previous cases that $\mathrm{PH} / \mathrm{PAH}$ can be improved by the addition of anti-neoplastic agents to the overall treatment regimen of patients with conditions that produce plasma cell dyscrasias, abnormal protein levels, and increased extracellular matrix deposition $[24,25,27,43,45,50,53$, $57-60,62,63,81-103]$. However, these therapies can produce adverse side effects that may potentially limit the 
number and type of treatments available for $\mathrm{PH}$, multiple myeloma, and other conditions associated with multisystem scleromyxedema [2-4, 6, 8, 10-12, 47, 53, 64-80]. Careful monitoring is necessary to mitigate adverse treatment effects in this patient population.

\section{Conclusion}

Although bortezomib and cyclophosphamide are generally used as second- and third-line treatments for scleromyxedema and related cutaneous mucinoses, these agents may be an effective primary therapy for these conditions in combination with glucocorticoids and/or proteasome inhibitors $[4,6,8,10,13,14,16-18,22-24,26,27,30,69,87]$ especially in the presence of plasma cell dyscrasia-associated $\mathrm{PAH}$. Treatment of our patient's underlying plasma cell abnormality with a combination treatment of cyclophosphamide, bortezomib, and dexamethasone not only reduced the population of abnormal plasma cells in the bone marrow but also improved the dermatological, cardiopulmonary, and paraprotein effects of scleromyxedema and multiple myeloma-induced $\mathrm{PH}$ as well similar to a few other previously reported cases $[24,25,27,60]$. Therefore, a combination regimen of cyclophosphamide, dexamethasone, and bortezomib may be an effective multi-target treatment for patients with $\mathrm{PH}$ refractory to vasodilator treatment, in the setting of plasma cell dyscrasias and elevated paraprotein levels. Additional work is necessary to understand the physiology of chemotherapeutic agents for $\mathrm{PAH}$-associated plasma cell dyscrasias and develop treatment regimens to maximize clinical response with minimal side effects.

\section{Abbreviations}

AHI: Apnea-Hypopnea Index; BNP: Brain natriuretic peptide; CPAP: Continuous positive airway pressure; CT: Computed tomography; DLCO: Diffusion lung capacity for carbon monoxide; eGFR: Estimated glomerular filtration rate; IgG: Immunoglobulin G; IU: International units; IVIG: Intravenous immunoglobulin; MGUS: Monoclonal gammopathy of unknown significance; MPN: Myeloproliferative neoplasms; NYHA: New York Heart Association; PAH: Pulmonary Arterial Hypertension; PH: Pulmonary Hypertension; POEMS: Polyneuropathy, organomegaly, endocrinopathy/ edema, M-protein, skin changes

\section{Acknowledgements}

The authors would like to thank Emily Andreae, PhD, and Marie Fleisner for manuscript preparation and submission.

\section{Authors' contributions \\ All authors contributed to the preparation of this manuscript and have read and approved the final manuscript. Individual contributions: MK managed the patient's pulmonary hypertension and led the preparation, writing, and revising of the manuscript. AAH tracked the patient's chemotherapy schedule and generated the treatment tables for this manuscript. RY is the rheumatologist representing the department who managed the patient's scleromyxedema and provided input from a rheumatological standpoint for the manuscript. JR prepared, analyzed, and interpreted pathology specimens.}

\section{Funding}

This work did not receive any specific grant from funding agencies in the public, commercial, or not-for-profit sectors.

\section{Availability of data and materials}

Data sharing is not applicable to this article, as no datasets were generated or analyzed during the current study. A complete listing of data from the patient's electronic medical record is unavailable for viewing, sharing, or dissemination per HIPAA guidelines.

\section{Ethics approval and consent to participate}

As this manuscript meets the definition of a case report, Institutional Review Board (IRB) review was not required for publication; the Marshfield Clinic Health System's IRB does not require written patient consent unless identifiable information (i.e., facial photographs) is published. Care was provided in accordance with standard-of-care procedures and best-practice recommendations at the health care system. Convenience.

\section{Consent for publication}

We confirm that we have obtained verbal consent to publish from the patient/participant to report the individual patient's data and medical images. Verbal consent was obtained from the patient. We have also now obtained written informed consent from the wife of the patient, after he passed away.

\section{Competing interests}

The authors declare that they have no competing interests.

\section{Author details}

${ }^{1}$ Department of Pulmonary and Critical Care Medicine, Marshfield Clinic, Marshfield, WI, USA. ${ }^{2}$ Department of Internal Medicine, Marshfield Clinic, Marshfield, WI, USA. ${ }^{3}$ Department of Rheumatology, Ronald Reagan UCLA Medical Center, Santa Monica, California, USA. ${ }^{4}$ Department of Pathology, Marshfield Clinic, Marshfield, WI, USA. ${ }^{5}$ Present affiliation: Christiana Care Health System, PO Box 1668, Wilmington, DE 19899, USA.

Received: 26 March 2019 Accepted: 6 December 2019

Published online: 09 January 2020

\section{References}

1. McCarthy JT, Osserman E, Lombardo PC, Takatsuki K. An abnormal serum globulin in lichen myxedematosus. Arch Dermatol. 1964;89:446-50.

2. Gabriel SE, Perry HO, Oleson GB, Bowles CA. Scleromyxedema: a scleroderma-like disorder with systemic manifestations. Medicine (Baltimore). 1988;67(1):58-65.

3. Dinneen AM, Dicken CH. Scleromyxedema. J Am Acad Dermatol. 1995;33(1):37-43.

4. Cokonis Georgakis CD, Falasca G, Georgakis A, Heymann WR. Scleromyxedema. Clin Dermatol 2006;24(6):493-7.

5. Blum M, Wigley FM, Hummers LK. Scleromyxedema: a case series highlighting long-term outcomes of treatment with intravenous immunoglobulin (IVIG). Medicine (Baltimore). 2008;87(1):10-20.

6. Rongioletti F, Merlo G, Cinotti E, Fausti V, Cozzani E, Cribier B, et al. Scleromyxedema: a multicenter study of characteristics, comorbidities, course, and therapy in 30 patients. J Am Acad Dermatol. 2013;69(1):66-72.

7. Rongioletti F, Merlo G, Carli C, Cribier B, Metze D, Calonje E, et al. Histopathologic characteristics of scleromyxedema: a study of a series of 34 cases. J Am Acad Dermatol. 2016;74(6):1194-200.

8. Rongioletti F. Scleromyxedema. Callen J, ed. UpToDate. Waltham: Wolters Kluwer. UpToDate Inc http://www.uptodate.com. Accessed on 22 Aug 2017.

9. Ferreli C, Gasparini G, Parodi A, Cozzani E, Rongioletti F, Atzori L. Cutaneous manifestations of scleroderma and scleroderma-like disorders: a comprehensive review. Clin Rev Allergy Immunol. 2017;53(3):306-36.

10. Knobler R, Moinzadeh P, Hunzelmann N, Kreuter A, Cozzio A, Mouthon L, et al. European dermatology forum S1-guideline on the diagnosis and treatment of sclerosing diseases of the skin, part 2: Scleromyxedema, scleredema and nephrogenic s ystemic fibrosis. J Eur Acad Dermatol Venereol. 2017:31(9):1581-94.

11. Rongioletti F. Lichen myxedematosus (papular mucinosis): new concepts and perspectives for an old disease. Semin Cutan Med Surg. 2006;25:100.

12. Alberts AS, Schulz EJ, Falkson G, Simson IW, Coccia-Portugal MA. Normalization of skin appearance in a patient with scleromyxoedema after intensive chemotherapy for Hodgkin's disease. Dermatol. 1989;178(4):221-4.

13. Giménez Garcia R, Garcia SG, Suarez Vilela D, Moro Sanchez MJ. Scleromyxedema associated with non-Hodgkin lymphoma. Int J Dermatol. 1989;28(10):670-1. 
14. Godby A, Bergstresser PR, Chaker B, Pandya AG. Fatal scleromyxedema: report of a case and review of the literature. J Am Acad Dermatol. 1998;38(2 Pt 2):289-94

15. Loggini B, Pingitore R, Avvenente A, Giuliano G, Barachini P. Lichen myxedematosus with systemic involvement: clinical and autopsy findings. J Am Acad Dermatol. 2001;45(4):606-8.

16. De Simone C, Castriota M, Carbone A, Marini Bettolo P, Pieroni M, Rongioletti F. Cardiomyopathy in scleromyxedema: Report of a fatal case. Eur J Dermatol. 2010;20(6):852-3.

17. Fett NM, Toporcer MB, Dalmau J, Shinohara MM, Vogl DT. Scleromyxedema and dermato-neuro syndrome in a patient with multiple myeloma effectively treated with dexamethasone and bortezomib. Am J Hematol. 2011:86(10):893-6

18. Sala AC, Cunha PR, Pinto CA, Alves CA, Paiva IB, Araujo AP. Scleromyxedema: clinical diagnosis and autopsy findings. An Bras Dermatol. 2016;91(5 suppl 1):48-50.

19. Muldrow ML, Bailin PL. Scleromyxedema associated with lgG lambda multiple myeloma. Cleve Clin Q. 1983 Summer;50(2):189-95.

20. Yeung CK, Loong F, Kwong YL. Scleromyxoedema due to a plasma cell neoplasm: rapid remission with bortezomib, thalidomide and dexamethasone. Br J Haematol. 2012;157(4):411.

21. Bos R, de Waal EG, Kuiper H, Hazenberg BP, Vellenga E. Thalidomide and dexamethasone followed by autologous stem cell transplantation for scleromyxoedema. Rheumatol (Oxf). 2011;50(10):1925-6.

22. Cañueto J, Labrador J, Román C, Santos-Briz A, Contreras T, et al. The combination of bortezomib and dexamethasone is an efficient therapy for relapsed/refractory scleromyxedema: A rare disease with new clinical insights. Eur J Haematol. 2012;88(5):450-4.

23. Migkou M, Gkotzamanidou M, Terpos E, Dimopoulos MA, Kastritis E. Response to bortezomib of a patient with scleromyxedema refractory to other therapies. Leuk Res. 2011;35(11):e209-11.

24. Yaqub S, Moder KG, Lacy MQ. Severe, reversible pulmonary hypertension in a patient with monoclonal gammopathy and features of dermatomyositis. Mayo Clin Proc. 2004;79(5):687-9.

25. Feyereisn WL, Fenstad ER, McCully RB, Lacy MQ. Severe reversible pulmonary hypertension in smoldering multiple myeloma: two cases and review of the literature. Pulm Circ. 2015;5(1):211-6.

26. Rather PA, Hussain M, Bagdadi F. Localized cutaneous mucinosis associated with multiple myeloma: A rare presentation. Indian J Dermatol. 2014;59(4):422.

27. Truhan AP, Roenigk HH Jr. Lichen myxedematosus. An unusual case with rapid progression and possible internal involvement. Int J Dermatol. 1987;26(2):91-5.

28. Kuldeep CM, Mittal AK, Gupta LK, Paliwal VK, Sharma P, Garg A. Successfu treatment of scleromyxedema with dexamethasone cyclophosphamide pulse therapy. Indian J Dermatol Venereol Leprol. 2005;71(1):44-5.

29. Feasel AM, Donato ML, Duvic M. Complete remission of scleromyxedema following autologous stem cell transplantation. Arch Dermatol. 2001;137:1071.

30. Ataergin S, Arpaci F, Demiriz M, Ozet A. Transient efficacy of double highdose chemotherapy and autologous peripheral stem cell transplantation, immunoglobulin, thalidomide, and bortezomib in the treatment of scleromyxedema. Am J Clin Dermatol. 2008;9(4):271-3.

31. Rayson D, Lust JA, Duncan A, Su WP. Scleromyxedema: A complete response to prednisone. Mayo Clin Proc. 1999 May;74(5):481-4.

32. Wright RC, Franco RS, Denton D, Blaney DJ. Scleromyxedema. Arch Dermatol. 1976 Jan;112(1):63-6.

33. Lin YC, Wang HC, Shen JL. Scleromyxedema: an experience using treatment with systemic corticosteroid and review of the published work. J Dermatol. 2006 Mar;33(3):207-10

34. Kreuter A, Altmeyer P. High-dose dexamethasone in scleromyxedema: report of 2 additional cases. J Am Acad Dermatol. 2005 Oct;53(4):739-40.

35. Horn KB, Horn MA, Swan J, Singhal S, Guitart J. A complete and durable clinical response to high-dose dexamethasone in a patient with scleromyxedema. J Am Acad Dermatol. 2004 Aug;51(2 Suppl):S120-3.

36. Lacy MQ, Hogan WJ, Gertz MA, Dispenzieri A, Rajkumar SV, Hayman S, et al. Successful treatment of scleromyxedema with autologous peripheral blood stem cell transplantation. Arch Dermatol. 2005 Oct;141(10):1277-82.

37. MacFarlane AW, Davenport A, Verbov JL, Goldsmith HJ. Scleromyxoedema-successful treatment with plasma exchange and immunosuppression. Br J Dermatol. 1987;117:653-7.

38. Keong CH, Asaka Y, Fukuro S, Miyamoto C, Katsumata M, lino Y, et al. Successful treatment of scleromyxedema with plasmapheresis and immunosuppression. J Am Acad Dermatol. 1990 May;22(5 Pt 1):842-4.
39. Hill TG, Crawford JN, Rogers CC. Successful management of lichen myxedematosus. Rep Case Arch Dermatol. 1976 Jan;112(1):67-9.

40. Morris-Jones R, Staughton RC, Walker M, Sheridan DJ, Rajappan K, Leonard J, et al. Lichen myxoedematosus with associated cardiac abnormalities. $\mathrm{Br}$ J Dermatol. 2001;144(3):594-6.

41. Bidier M, Zschoche C, Gholam P, Enk AH, Hadaschik EN. Scleromyxoedema: clinical follow-up after successful treatment with high-dose immunoglobulins reveals different long-term outcomes. Acta Derm Venereol. 2012:92(4):408-9.

42. Galiè N, Humbert M, Vachiery JL, Gibbs S, Lang I, Torbicki A, et al. 2015 ESC/ ERS guidelines for the diagnosis and treatment of pulmonary hypertension. The joint task force for the diagnosis and treatment of pulmonary hypertension of the European Society of Cardiology (ESC) and the European Respiratory Society (ERS). Eur Respir J. 2015;46(4):1855-6.

43. Marvin KS, Spellberg RD. Pulmonary hypertension secondary to thrombocytosis in a patient with myeloid metaplasia. Chest. 1993;103(2):642-4.

44. Nand S, Orfei E. Pulmonary hypertension in polycythemia vera. Am J Hematol. 1994;47(3):242-4.

45. Rossoff LJ, Genovese J, Coleman M, Dantzker DR. Primary pulmonary hypertension in a patient with CD8/T-cell large granulocyte leukemia: amelioration by cladribine therapy. Chest. 1997;112(2):551-3.

46. García-Manero G, Schuster SJ, Patrick H, Martinez J. Pulmonary hypertension in patients with myelofibrosis secondary to myeloproliferative diseases. Am J Hematol. 1999;60(2):130-5.

47. Dingli D, Utz JP, Krowka MJ, Oberg AL, Tefferi A. Unexplained pulmonary hypertension in chronic myeloproliferative disorders. Chest. 2001;120(3):801-8.

48. Steensma DP, Hook CC, Stafford SL, Tefferi A. Low-dose, single-fraction, whole-lung radiotherapy for pulmonary hypertension associated with myelofibrosis with myeloid metaplasia. Br J Haematol. 2002;118(3):813-6.

49. Popat U, Frost A, Liu E, May R, Bag R, Reddy V, et al. New onset of myelofibrosis in association with pulmonary arterial hypertension. Ann Intern Med. 2005;143(6):466-7.

50. Rostagno C, Ciolli S. Transient severe symptomatic pulmonary hypertension as onset symptom in multiple myeloma. Ann Hematol. 2006:85(9):627-8.

51. Cortelezzi A, Gritti G, Del Papa N, Pasquini MC, Calori R, Gianelli U, et al. Pulmonary arterial hypertension in primary myelofibrosis is common and associated with an altered angiogenic status. Leukemia. 2008;22(3):646-9.

52. Willems E, Canivet JL, Ghaye B, de Leval L, Radermecker M, et al. Pulmonary venoocclusive disease in myeloproliferative disorder. Eur Respir J. 2009:33(1):213-6.

53. Adir $Y$, Elia D, Harari S. Pulmonary hypertension in patients with chronic myeloproliferative disorders. Eur Respir Rev. 2015;24(137):400-10.

54. Krishnan U, Mark TM, Niesvizky R, Sobol I. Pulmonary hypertension complicating multiple myeloma. Pulm Circ. 2015;5(3):590-7.

55. Roach EC, Park MM, Tang WH, Thomas JD, Asosingh K, Kalaycio M, et al. Impaired right ventricular-pulmonary vascular function in myeloproliferative neoplasms. J Heart Lung Transplant. 2015;34(3):390-4.

56. Mattar MM, Morad MA, El Husseiny NM, Ali NH, El Demerdash DM. Correlation between JAK2 allele burden and pulmonary arterial hypertension and hematological parameters in Philadelphia negative JAK2 positive myeloproliferative neoplasms. Ann Hematol. 2016;95(10):1611-6.

57. Montani D, Achouh L, Marcelin AG, Viard JP, Hermine O, Canioni D, et al. Reversibility of pulmonary arterial hypertension in HIV/HHV8-associated Castleman's disease. Eur Respir J. 2005 Nov;26(5):969-72.

58. Taytawat P. Reversible pulmonary hypertension and isolated right heart failure associated with multiple myeloma. Chest. 2013;144(4 Meeting Abstracts):155A.

59. Tamura S, Koyama A, Shiotani C, Kurihara T, Nishikawa A, Okamoto Y, et al. Successful bortezomib/dexamethasone induction therapy with lenalidomide in an elderly patient with primary plasma cell leukemia complicated by renal failure and pulmonary hypertension. Intern Med. 2014;53(11):1171-5.

60. Warsame R, Kohut IE, Dispenzieri A. Successful use of cyclophosphamide, bortezomib, and dexamethasone to treat a case of relapsed POEMS. Eur J Haematol. 2012;88(6):549-50.

61. Adam Z, Krejčí M, Pour L, Feit J, Büchler T, Hájek R. IgA pemphigus associated with monoclonal gammopathy completely resolved after achievement of complete remission of multiple myeloma with bortezomib, cyclophosphamide and dexamethasone regimen. Wien Klin Wochenschr. 2010:122(9-10):311-4

62. Chinen K, Fujioka Y. Severe pulmonary hypertension caused by smoldering plasma cell myeloma: an autopsy case of POEMS syndrome. Case Rep Med. 2012:836893. 
63. Fox A, Farr G, Grinnan D. Improvement in pulmonary arterial hypertension associated with Castleman's disease after treatment with ambrisentan and rituximab. Chest. 2015 Oct;148(4 Supp):994A.

64. Miyakoshi S, Kami M, Yuji K, Matsumura T, Takatoku M, Sasaki M, et al. Severe pulmonary complications in Japanese patients after bortezomib treatment for refractory multiple myeloma. Blood. 2006;107(9):3492-4.

65. Boyer JE, Batra RB, Ascensao JL, Schechter GP. Severe pulmonary complication after bortezomib treatment for multiple myeloma. Blood. 2006;108(3):1113.

66. Gotoh A, Ohyashiki K, Oshimi K, Usui N, Hotta T, et al. Lung injury associated with bortezomib therapy in relapsed/refractory multiple myeloma in Japan: a questionnaire-based report from the "lung injury by Bortezomib" joint committee of the Japanese Society of Hematology and the Japanese Society of Clinical Hematology. Int J Hematol. 2006;84(5):406-12.

67. Ohri A, Arena FP. Severe pulmonary complications in African-American patient after bortezomib therapy. Am J Ther. 2006;13(6):553-5.

68. Chew E, Filshie R, Wei A. Development of fatal bortezomib induced acute lung injury despite concurrent therapy with high-dose dexamethasone. Leuk Lymphoma. 2007:48(1):212-3.

69. Duek A, Feldberg E, Haran M, Berrebi A. Pulmonary fibrosis in a myeloma patient on bortezomib treatment. A new severe adverse effect of a new drug. Am J Hematol. 2007;82(6):502-3.

70. Pitini V, Arrigo C, Altavilla G, Naro C. Severe pulmonary complications after bortezomib treatment for multiple myeloma: an unrecognized pulmonary vasculitis? Leuk Res. 2007:31(7):1027-8.

71. Zappasodi P, Dore R, Castagnola C, Astori C, Varettoni M, et al. Rapid response to high-dose steroids of severe bortezomib-related pulmonary complication in multiple myeloma. J Clin Oncol. 2007;25(22):3380-1.

72. Lafaras C, Mandala E, Verrou E, Platogiannis D, Barbetakis N, et al. Nonthromboembolic pulmonary hypertension in multiple myeloma, after thalidomide treatment: a pilot study. Ann Oncol. 2008;19(10):1765-9.

73. Ghose A, Tariq Z, Taj A, Chaudhary R. Acute dyspnea from treatment of AL amyloidosis with bortezomib. Am J Ther. 2011;18(4):e123-5.

74. Montani D, Bergot E, Günther S, Savale L, Bergeron A, Bourdin A, et al. Pulmonary arterial hypertension in patients treated by dasatinib. Circ. 2012; 125(17):2128-37.

75. Akosman C, Ordu C, Eroglu E, Oyan B. Development of acute pulmonary hypertension after bortezomib treatment in a patient with multiple myeloma: a case report and the review of the literature. Am J Ther. 2015; 22(3):e88-92.

76. Sugita Y, Ohwada C, Nagao Y, Kawajiri C, Shimizu R, Togasaki E, et al. Earlyonset severe diffuse alveolar hemorrhage after bortezomib administration suggestive of pulmonary involvement of myeloma cells. J Clin Exp Hematop. 2015;55(3):163-8.

77. Ranchoux B, Günther S, Quarck R, Chaumais MC, Dorfmüller P, Antigny F, et al. Chemotherapy-induced pulmonary hypertension: role of alkylating agents. Am J Pathol. 2015;185(2):356-71.

78. Dumitrescu D, Seck C, ten Freyhaus H, Gerhardt F, Erdmann E, Rosenkranz S Fully reversible pulmonary arterial hypertension associated with dasatinib treatment for chronic myeloid leukaemia. Eur Respir J. 2011 Jul;38(1):218-20.

79. Meka S, Otoupalova E, Patel V, Cichewiz A, Dalal B. Rituximab: Friend or foe for PAH? 2016 Oct; 150(4 Supp):1215A.

80. Montrone D, Correale M, Franzese MG, leva R, Di Biase M, Capalbo SF. Pulmonary arterial hypertension in a chronic lymphocytic leukemia patient in treatment with rituximab. J Cardiovasc Med (Hagerstown). 2015 Jan; 16(Suppl 1):S65.

81. Spiekerkoetter E, Sung YK, Sudheendra D, Bill M, Aldred MA, van de Veerdonk MC, et al. Low-dose FK506 (Tacrolimus) in end-stage pulmonary arterial hypertension. Am J Respir Crit Care Med. 2015 Jul 15;192(2):254-7.

82. Spiekerkoetter E, Tian X, Cai J, Hopper RK, Sudheendra D, Li CG, et al. FK506 activates BMPR2, rescues endothelial dysfunction, and reverses pulmonary hypertension. J Clin Invest. 2013 Aug;123(8):3600-13.

83. Schermuly RT, Dony E, Ghofrani HA, Pullamsetti S, Savai R, Roth M, et al. Reversal of experimental pulmonary hypertension by PDGF inhibition. J Clin Invest. 2005 Oct;115(10):2811-21.

84. Kamata Y, Nara H, Sato H, Masuyama Jl, Minota S, Yoshio T. Effect of steroid pulse therapy on mixed connective tissue disease with pulmonary arterial hypertension. Ann Rheum Dis. 2005 Aug;64(8):1236-7.

85. Harbaum L, Hennigs JK, Baumann HJ, Bokemeyer C, Olschewski H, Klose H. Complete resolution of idiopathic pulmonary arterial hypertension following chemotherapy. Eur Respir J. 2014 May;43(5):1513-5.
86. Ferri C, Emdin M, Storino FA, Giuggioli D, Longombardo G, Greco F, et al. Isolated pulmonary hypertension in diffuse cutaneous systemic sclerosis successfully treated with long-term plasma exchange. Scand J Rheumatol. 2000;29(3):198-200.

87. Meloche J, Renard S, Provencher S, Bonnet S. Anti-inflammatory and immunosuppressive agents in PAH. Handb Exp Pharmacol. 2013;218:437-76.

88. Ogawa A, Nakamura K, Mizoguchi H, Fujii N, Fujio H, Kusano KF, et al. Prednisolone ameliorates idiopathic pulmonary arterial hypertension. Am J Respir Crit Care Med. 2011 Jan 1;183(1):139-40.

89. Bellotto F, Chiavacci P, Laveder F, Angelini A, Thiene G, Marcolongo R. Effective immunosuppressive therapy in a patient with primary pulmonary hypertension. Thorax. 1999 Apr;54(4):372-4.

90. Aggarwal M. Grady RM1. Glucocorticoids for treating paediatric pulmonary hypertension: a novel use for a common medication. Cardiol Young. 2017 Sep;27(7):1410-2.

91. Haritha J, Syed H, Nandan A, Grinnan D. Report shows rituximab may help treat MCTD-associated PAH. Rheumatologist. 2018 April 26.

92. Hennigan S, Channick RN, Silverman GJ. Rituximab treatment of pulmonary arterial hypertension associated with systemic lupus erythematosus: a case report. Lupus. 2008 Aug;17(8):754-6.

93. Padilla-lbarra J, Sanchez-Ortiz A, Sandoval-Castro C, Ramos-Remus C. Rituximab treatment for pulmonary arterial hypertension in adult-onset Still's disease. Clin Exp Rheumatol. 2013 Jul-Aug;31(4):657-8.

94. Dandel M, Wallukat G, Englert A, Hetzer R. Immunoadsorption therapy for dilated cardiomyopathy and pulmonary arterial hypertension. Atheroscler Suppl. 2013 Jan;14(1):203-11.

95. Nagel C, Ewert R, Egenlauf B, Lehmkuhl HB, Rosenkranz S, Benjamin N, et al. Safety and efficacy of immunoadsorption as an add-on to medical treatment in patients with severe idiopathic pulmonary arterial hypertension. Respir. 2017;94(3):263-71.

96. Wang W, Wang YL, Chen XY, Li YT, Hao W, Jin YP, et al. Dexamethasone attenuates development of monocrotaline-induced pulmonary arterial hypertension. Mol Biol Rep. 2011 Jun;38(5):3277-84.

97. Price LC, Montani D, Tcherakian C, Dorfmüller P, Souza R, Gambaryan N, et al. Dexamethasone reverses monocrotaline-induced pulmonary arterial hypertension in rats. Eur Respir J. 2011 Apr:37(4):813-22.

98. Kim SY, Lee JH, Huh JW, Kim HJ, Park MK, et al. Bortezomib alleviates experimental pulmonary arterial hypertension. Am J Respir Cell Mol Biol. 2012;47(5):698-708.

99. Wang $Y Y$, Luan $Y$, Zhang $X$, Lin M, Zhang ZH, et al. Proteasome inhibitor PS341 attenuates flow-induced pulmonary arterial hypertension. Clin Exp Med. 2014;14(3):321-9.

100. Zhang $X$, Wang ZS, Luan Y, Lin M, Zhu XB, Ma Y, et al. The effect of PS-341 on pulmonary vascular remodeling in high blood flow-induced pulmonary hypertension. Int J Mol Med. 2014;33(1):105-10.

101. Zhang J, Lu W, Chen Y, Jiang Q, Yang K1, Li M, et al. Bortezomib alleviates experimental pulmonary hypertension by regulating intracellular calcium homeostasis in PASMCs. Am J Physiol Cell Physiol 2016;311(3):C482-C497.

102. Zhu Y, Wu Y, Shi W, Wang J, Yan X, Wang Q, et al. Inhibition of ubiquitin proteasome function prevents monocrotaline-induced pulmonary arterial remodeling. Life Sci. 2017;173:36-42.

103. Ibrahim YF, Wong CM, Pavlickova L, Liu L, Trasar L, et al. Mechanism of the susceptibility of remodeled pulmonary vessels to drug-induced cell killing. J Am Heart Assoc. 2014;3(1):e000520.

104. Rongioletti F, Cattarini G, Sottofattori E, Rebora A. Granulomatous reaction after intradermal injections of hyaluronic acid gel. Arch Dermatol. 2003 Jun;139(6):815-6.

105. Price LC, Wort SJ, Perros F, Dorfmüller P, Huertas A, Montani D, et al. Inflammation in pulmonary arterial hypertension. Chest. 2012 Jan;141(1):210-21.

106. Yuan JX, Rubin LJ. Pathogenesis of pulmonary arterial hypertension: the need for multiple hits. Circ. 2005 Feb 8;111(5):534-8.

107. Boucherat O, Vitry G, Trinh I, Paulin R, Provencher S, Bonnet S. The cancer theory of pulmonary arterial hypertension. Pulm Circ. 2017 Apr-Jun;7(2):285-99.

108. Tamby MC, Chanseaud Y, Humbert M, Fermanian J, Guilpain P, Garcia-de-la-PeñaLefebvre $\mathrm{P}$, et al. Anti-endothelial cell antibodies in idiopathic and systemic sclerosis associated pulmonary arterial hypertension. Thorax. 2005 Sep;60(9):765-72.

109. Tamby MC, Humbert M, Guilpain P, Servettaz A, Dupin N, Christner JJ, et al. Antibodies to fibroblasts in idiopathic and scleroderma-associated pulmonary hypertension. Eur Respir J. 2006 Oct;28(4):799-807.

110. Guignabert C, Tu L, Le Hiress M, Ricard N, Sattler C, Seferian A, et al. Pathogenesis of pulmonary arterial hypertension: lessons from cancer. Eur Respir Rev. 2013 Dec;22(130):543-51. 
111. Stacher E, Graham BB, Hunt JM, Gandjeva A, Groshong SD, McLaughlin W, et al. Modern age pathology of pulmonary arterial hypertension. Am J Respir Crit Care Med. 2012 Aug 1;186(3):261-72.

112. Kawamura N, Tsutsui H, Fukuyama K, Hayashidani S, Koike G, Egashira K, et al. Severe pulmonary hypertension in a patient with systemic lupus erythematosus and minimal lupus activity. Intern Med. 2002 Feb;41 (2):109-12.

113. Mukerjee D, St George D, Coleiro B, Knight C, Denton CP, Davar J, et al. Prevalence and outcome in systemic sclerosis associated pulmonary arterial hypertension: application of a registry approach. Ann Rheum Dis. 2003 Nov; 62(11):1088-93.

114. Bordley JE, Carey RA, et al. Preliminary observations on the effect of adrenocorticotropic hormone in allergic diseases. Bull Johns Hopkins Hosp. 1949 Nov;85(5):396-8.

115. Röllig C, Knop S, Bornhäuser M. Multiple myeloma. Lancet. 2015 May 30; 385(9983):2197-208.

116. Weiner GJ. Rituximab: mechanism of action. Semin Hematol. 2010 Apr;47(2):115-23.

117. Richardson PG, Weller E, Lonial S, Jakubowiak AJ, Jagannath S, Raje NS, et al. Lenalidomide, bortezomib, and dexamethasone combination therapy in patients with newly diagnosed multiple myeloma. Blood. 2010 Aug 5;116(5):679-86.

118. Lub S, Maes K, Menu E, De Bruyne E, Vanderkerken K, Van Valckenborgh E. Novel strategies to target the ubiquitin proteasome system in multiple myeloma. Oncotarget. 2016;7(6):6521-37.

\section{Publisher's Note}

Springer Nature remains neutral with regard to jurisdictional claims in published maps and institutional affiliations.

Ready to submit your research? Choose BMC and benefit from:

- fast, convenient online submission

- thorough peer review by experienced researchers in your field

- rapid publication on acceptance

- support for research data, including large and complex data types

- gold Open Access which fosters wider collaboration and increased citations

- maximum visibility for your research: over $100 \mathrm{M}$ website views per year

At BMC, research is always in progress.

Learn more biomedcentral.com/submissions 